\title{
INFLUENCE OF ZEOLITES ON THE PHYSIOLOGICAL PROCESSES IN TISSUES OF PLANT REPRODUCTIVE ORGANS
}

\author{
Ovchinnikov A.S., Corresponding Member of RAS, \\ Podkovyrov I.Y.*, Candidate of Agricultural Sciences, \\ Dolgova A.I., Post-graduate student \\ Volgograd State Agrarian University, Volgograd, Russia \\ *E-mail: agrosad@inbox.ru
}

\begin{abstract}
The stabilizing effect of zeolite on the $\mathrm{pH}$ and $\mathrm{EC}$ indices of soils for growing tomato has been revealed in this study. A close relationship (0.75-0.91) between the electrical conductivity of aqueous extract from zeolite and germination in laboratory, the germination energy, the growth activity of root tissues in the early stages of ontogeny was established. Spraying with zeolite nanoparticles reduces the water deficiency in the epidermis and the loss of fruit water (by 35\%), which improves their commercial quality during storage. Suppression of pathogenic microflora causing fruits rot is noted at level of 48 to $75 \%$.
\end{abstract}

\section{KEY WORDS}

Zeolite, growth processes, water deficiency, plant tissues, tomato, reproductive organs.

Management of the physiological processes of plant tissues is a key issue in reproductive biology in the production of tomato fruit [1]. The normal course of growth processes, development, providing tissues with water and the necessary elements of life activity is possible due to the use of innovative materials [2]. In modern production, stimulators of growth processes of chemical nature, the so-called "growth hormones": auxins, cytokinins, gibberellins became widespread. They find application primarily to accelerate the intensity of cell division and tissue differentiation into organs. The effectiveness of their action is difficult to control in production conditions, since methods for determining the concentration of hormones in plant tissues are complex. Namely, the ratio of the concentrations of various types of hormones determines the intensity of the course of physiological processes [3].

One of the new directions in managing the growth of plants is using natural resources for these purposes. The physiological activity of bischofites, sapropels, and peats has been sufficiently studied. Zeolites are also promising for use in vegetable growing. Their properties as meliorants and adsorbents were studied. They also have a number of advantages that are not fully investigated, but can be used to control physiological processes [4].

Zeolites have a unique chemical composition. The main component in the chemical structure is clinoptilolite, its share reaches $77 \%$. This substance provides a high ionexchange capacity of the structures $(1.5 \mathrm{mg} \mathrm{eq} / \mathrm{g})$. Zeolites adsorb ions of mercury, cadmium, lead, copper, strontium from the liquids. At the same time, they are the source of silicon, iron, manganese, fluorine and other useful elements. Zeolites are classified as environmentally friendly materials. Their using in vegetable growing will make it possible to receive organic products that are valuable for human nutrition. The structure of the crystal lattice makes it possible to adsorb and to give off moisture, which is important in regulating the water regime [5].

The aim of the studies was to study the effect of zeolites on growth activity and the water regime of the tissues of tomato reproductive organs that allows developing methods of growing plants and storing fruits.

\section{MATERIALS AND METHODS OF RESEARCH}

The study of the biological effectiveness of zeolites was carried out in two directions. In the first, the effect of different concentration of mineral fine fractions on the properties of 
aqueous extracts of soils used in vegetable growing was investigated. To do this, peat soil, coconut, sand, light chestnut soil with zeolite was mixed in the ratios of 1:1, 1:4. An aqueous extract was prepared from the mixture according to the generally accepted procedure (GOST 26483-85) and its properties were studied by electrophysical methods.

At the second stage, the effect of aqueous extract from zeolites on the physiological processes during the germination of seeds was studied. To do this, the tomato seeds of the variety "Podarochny" were germinated on a water extract prepared with the addition of zeolites of $1,5,10,15$ and $20 \mathrm{~g} / \mathrm{l}$. Germination was carried out in Petri dishes at a temperature of $22-23{ }^{\circ} \mathrm{C}$. We studied the germination energy, laboratory germination, the activity of growth processes in the root according to generally accepted methods (GOST 12038-84, GOST 12039-82, GOST 32592-2013) [6, 7, 8, 9, 10].

The influence of zeolites on the water regime of the top cover tissues of tomato fruits was studied during the storage period. For this, the fruit was coated with a thin layer of zeolite of the fraction 0.0001-0.001 microns. The loss of water by the tissues during storage at the temperature of $5-6^{\circ} \mathrm{C}$ was noted. The change in fruit quality was evaluated according to the criteria of GOST R 55906-2013.

\section{RESULTS AND DISCUSSION}

The meliorative properties of zeolites are well known. When applied to the soil, it improves the structure, enriches it with trace elements, absorbs pollutants. However, studies related to the investigation of meliorative properties were carried out on soils in the open field. With the development of vegetable crops production in greenhouses on artificial substrates, the use of zeolite in soil preparation technology becomes particularly urgent. Manufacturers recommend this material in low-volume hydroponics. These technologies are not developed due to the absence of extensive research, in this connection zeolite is not introduced into the practice of vegetable growing.

The study of zeolites effect on the physical and chemical characteristics of various soils has shown the possibility of optimizing their composition. In southern regions, more than $75 \%$ of the protected ground is temporary shelters (greenhouses), where tomatoes and cucumbers are grown directly in the soil. However, light chestnut soils have an excessively alkaline $\mathrm{pH}$ reaction, a high content of readily soluble salts. This creates an unfavorable nutritional regime for plants. The introduction of zeolite into the soil makes it possible to lower the $\mathrm{pH}$ to 8.0 and to reduce the concentration of readily soluble salts by $17.6 \%$.

The sand has more favorable $\mathrm{pH}$ values of 7.5. The salt content is very low (about 0.06 $\mathrm{g} / \mathrm{l})$. Adding zeolite to sandy soils allows to increase the electrical conductivity index up to 1.2 $\mathrm{mS} / \mathrm{cm}$, which means improving the colloid-osmotic properties of the substrate and the regime of mineral nutrition of plants (Table 1).

Table 1 - Effect of zeolite on the properties of water extracts of soils used in greenhouses

\begin{tabular}{|l|c|c|c|}
\hline \multirow{2}{*}{ Soil composition } & \multicolumn{3}{c|}{ Physicochemical parameters of water extract } \\
\cline { 2 - 4 } & $\mathrm{pH}$ & $\begin{array}{c}\text { The content of readily } \\
\text { soluble salts, g/l }\end{array}$ & $\begin{array}{c}\text { Electrical conductivity (EC), } \\
\text { mS/cm }\end{array}$ \\
\hline Light chestnut soil & 8.5 & 0.17 & 1.7 \\
\hline Zeolite & 8.0 & 0.24 & 1.2 \\
\hline Soil $50 \%+$ zeolite $50 \%$ & 8.3 & 0.16 & 1.5 \\
\hline Soil 75\% + zeolite $25 \%$ & 8.0 & 0.14 & 1.6 \\
\hline Sand & 7.5 & 0.06 & 1.9 \\
\hline Sand $50 \%+$ zeolite $50 \%$ & 7.9 & 0.13 & 1.1 \\
\hline Sand $75 \%+$ zeolite $25 \%$ & 7.8 & 0.09 & 1.3 \\
\hline Peat & 5.1 & 0.24 & 1.5 \\
\hline Peat $50 \%+$ zeolite $50 \%$ & 5.8 & 0.15 & 1.4 \\
\hline Peat $75 \%+$ zeolite $25 \%$ & 5.4 & 0.19 & 1.8 \\
\hline Coconut fiber & 6.2 & 0.34 & 1.5 \\
\hline Coconut fiber 50\% + zeolite $50 \%$ & 6.0 & 0.39 & \\
\hline
\end{tabular}


Peat is widely used in growing seedlings. However, it has an acid reaction (in our experiments $\mathrm{pH}$ 5.1). Zeolite is largely regulates this index, increasing it to favorable levels of 5.4 - 5.8 when growing tomato, cucumber, strawberry. Also, the EC (electrical conductivity) of water extract with addition of zeolite to peat is also increased to the recommended values $(1.4-1.5 \mathrm{mS} / \mathrm{cm})$.

Coconut fiber contains a significant amount of readily soluble salts $0.34 \mathrm{~g} / \mathrm{l}$ (twice as much as in light chestnut soil). Zeolite slightly reduces the acidity (by $3.2 \%$ ) and electrical conductivity (by $16.7 \%$ ), which also creates favorable conditions for the mineral nutrition of plants.

The greatest effect is observed when zeolite is added to light chestnut soil, peat and coconut fiber. For improving the structure, physical and chemical parameters of the soil, it is possible to recommend adding zeolite in the amount of $25 \%$ of weight, and for peat and coconut fiber $-50 \%$.

The biological effectiveness of the zeolite is of interest. The complex of compounds that passes into the solution in the substrate affects the course of physiological processes in the tissues during the germination of seeds. This phenomenon was studied on the tissues of tomato seedlings when germinated in zeolite aqueous extract in various concentrations (Table 2).

Table 2 - Effect of different concentrations of zeolites aqueous extract on the germination of tomato seeds

\begin{tabular}{|c|c|c|c|c|c|}
\hline $\begin{array}{c}\text { Variants } \\
\text { of aqueous } \\
\text { extraction } \\
\text { of zeolites }\end{array}$ & $\begin{array}{c}\text { Electrical } \\
\text { conductivity } \\
(\mathrm{EC}), \mathrm{mS} / \mathrm{cm}\end{array}$ & $\begin{array}{c}\text { Laboratory } \\
\text { germination, } \\
\%\end{array}$ & $\begin{array}{c}\text { Energy } \\
\text { of germination, } \\
\text { days }\end{array}$ & $\begin{array}{c}\text { Root length } \\
\text { on the day } \\
\text { of counting, } \\
\mathrm{mm}\end{array}$ & $\begin{array}{c}\text { Growth activity } \\
\text { of tissues in } \\
\text { comparison with the } \\
\text { control, mm per day }\end{array}$ \\
\hline Control (water) & 0.05 & 87.3 & 6 & 19.2 & 3.2 \\
\hline $1 \mathrm{~g} / \mathrm{l}$ & 0.3 & 91.1 & 5 & 23.5 & 4.7 \\
\hline $5 \mathrm{~g} / \mathrm{l}$ & 0.6 & 95.6 & 5 & 24.1 & 4.8 \\
\hline $10 \mathrm{~g} / \mathrm{l}$ & 0.7 & 97.2 & 5 & 24.7 & 4.9 \\
\hline $15 \mathrm{~g} / \mathrm{l}$ & 0.9 & 97.6 & 5 & 24.7 & 4.9 \\
\hline $20 \mathrm{~g} / \mathrm{l}$ & 1.2 & 97.5 & 5 & 24.6 & 0.02 \\
\hline Average & - & 94.4 & - & 23.5 & \\
\hline $\begin{array}{c}\text { Smallest } \\
\text { significant }\end{array}$ & & 0.21 & & 0.09 & \\
\hline difference $(0,05)$ & & & & & \\
\hline
\end{tabular}

In laboratory experiments, the positive effect of aqueous extract from zeolite on growth processes during the germination of tomato seeds was established. In all variants, the excess over the control was observed at the rate of laboratory germination by $4.35-11.8 \%$. The energy of seed germination increased, as a result of which the period of appearance of the root decreased to 5 days. There was also an increase in root growth activity in the experimental variants compared with the control. The length of the sprouts roots in zeolite extracts exceeded the control by $22.4-28.6 \%$.

Zeolite, as a natural mineral, does not contain the substances of hormonal nature. Nevertheless, it has a positive effect on the growth processes of root tissues in the early stages of plant development. Apparently, this effect is due to the action of the complex of microelements, which move into aqueous extract and then enter the seed tissues and include in biochemical processes.

A close relationship was established between the EC of water extract index and the laboratory germination of tomato seeds $\left(r^{2}=0.91\right)$, the length of the sprout root $(r 2=0.79)$, the growth activity of the root tissues $\left(r^{2}=0.75\right)$. This proves the positive effect of watersoluble zeolite components on the physiological processes occurring in plant tissues. Enrichment of substrates with zeolite allows activating growth processes at the initial stages of ontogenesis after seeds germination.

The stable biological effectiveness of zeolites was observed in all experimental variants. However, in aqueous extracts with its addition of 1 to $10 \mathrm{~g} / \mathrm{l}$, the laboratory germinability and growth activity increases, and at the rate of 15 and $20 \mathrm{~g} / \mathrm{l}$ remains at the 
same level. The maximum biological efficiency is observed in the variant of aqueous extract of $10 \mathrm{~g} / \mathrm{l}$ zeolite for all the investigated parameters. It can be recommended to use this option in practice to stimulate the germination of tomato seeds.

Treatment of tomato fruit with zeolite has been poorly studied, although it is a very effective and efficient method of reducing losses and prolonging the shelf life by many indicators [11]. This feature is due to the high content of zeolite clinoptilolites. These compounds have porous structure of the crystal lattice and possess a moisture adsorbing. During storage tomato fruits evaporate water, which condenses on the surface of the skin and leads to the development of the pathogenic microflora. Zeolites are able to absorb and bind excess moisture, improving the storage conditions of fruits (Table 3 ).

Table 3 - Effect of zeolite on the water regime of tomato fruit under different storage conditions

\begin{tabular}{|c|c|c|c|c|}
\hline Variant & $\begin{array}{c}\text { Loss of } \\
\text { moisture, } \%\end{array}$ & $\begin{array}{c}\text { Development of } \\
\text { rot, score }\end{array}$ & $\begin{array}{c}\text { Duration of storage } \\
\text { unchanged, days }\end{array}$ & $\begin{array}{c}\text { Exceeding } \\
\text { control, times }\end{array}$ \\
\hline $\begin{array}{c}\text { Fruits of tomato, processed with } \\
\text { zeolite, storage at a temperature } \\
\text { of } 24-25^{\circ} \mathrm{C}\end{array}$ & 13.6 & 1.9 & 8 & 2.7 \\
\hline $\begin{array}{c}\text { Tomato fruits without treatment } \\
(\text { control), storage at temperature } \\
24-25^{\circ} \mathrm{C}\end{array}$ & 24.9 & 3.7 & 3 & - \\
\hline $\begin{array}{c}\text { Tomato fruits, processed with } \\
\text { zeolite, storage at temperature } \\
4-5^{\circ} \mathrm{C}\end{array}$ & 5.3 & 0.6 & 23 & 2.1 \\
\hline $\begin{array}{c}\text { Tomato fruits without treatment } \\
\text { (control), storage at temperature } \\
4-5^{\circ} \mathrm{C}\end{array}$ & 16.1 & 2.4 & 11 & - \\
\hline $\begin{array}{c}\text { Smallest significant difference } \\
(0,05)\end{array}$ & 0.12 & 0.02 & - & - \\
\hline
\end{tabular}

It has been established that the coating of fruits with zeolite with particle size of 0.001 $0.0001 \mathrm{~mm}$ positively affects both the hydration of the skin tissues of the fruit surface and suppresses the development of pathogenic microflora.

Excessive moisture leads to increased respiration, lower dry matter content, sharp deterioration in quality and loss of product. When storing fruits, it is important to properly regulate the water regime of tissues. Zeolite provides both the absorption of excess moisture formed during evaporation, and its return back to the deficit in the epidermis and flesh. Under storage conditions at a temperature of $24-25^{\circ} \mathrm{C}$, the loss of water in fruits covered with zeolite is reduced 1.8 times, and the stable course of physiological processes occurs when stored for up to 8 days. Low temperatures of $4-5^{\circ} \mathrm{C}$ reduce moisture loss by $35.3 \%$. However, the use of a coating of zeolite enhances the moisture-saving effect by a factor of 3 .

When the fruit surface is powdered with zeolite, the development of pathogenic microflora causing rotting is suppressed. The development of fruit rot was reduced with warm storage by $48.6 \%$, and in the cold - by $75.0 \%$. This prolonged the storage period of tomato fruits in 2.1-2.7 times.

\section{CONCLUSION}

Improving the water regime of the epidermis is achieved by creating favorable humidity conditions around the fruit, excluding the condensation of water on their surface. In addition, the stimulator of fruit ripening, destruction of starch molecules into mono- and disaccharides is ethylene, which is released as a result of respiration. Zeolite adsorbs this substance on the crystalline lattice of clinoptilolite, preventing softening of the fetal tissues as a result of their maturation. Thus, positive effect of zeolite on the physiological processes of plant tissues was revealed. A stimulating effect on the growth processes of root tissues of tomato seedlings was established. In the composition of soils for greenhouses, the zeolite stabilizes the $\mathrm{pH}$ and the EC providing favorable conditions for the development of plants. The use of zeolite to prolong the shelf life of tomato fruit has shown high efficiency. Biologically active 
adsorbent, due to the combined effect of chemical and physical adsorption of natural clinoptilolites included in its composition, provides favorable water regime of fruits during storage.

\section{REFERENCES}

1. Gavrish S.F. Tomato: cultivation and processing: training allowance // Moscow: Rosagropromizdat, 1990. - 190 p.

2. Soldatenko A.V. Features of the accumulation of radionuclides in various food bodies of vegetable crops // Vegetables of Russia, No. 3-4 (28-29), 2015, pp. 39-43.

3. Polevoy V.V. Workshop on the growth and stability of plants // L., 2001. - 212 p.

4. Dolgova A.I. et al. The way of processing fruits and vegetables before depositing them // Patent for invention No. 2615825, 2017.

5. Dolgova, A.I. et al. The way of storing agricultural products // Patent for invention No. 2616845, 2017.

6. GOST 26483-85 "Soils. Preparation of salt extract and determination of its $\mathrm{pH}$ by the method of CINAO".

7. GOST 12038-84 "Seeds of agricultural crops. Methods of determination of germination".

8. GOST 12039-82 "Seeds of agricultural crops. Methods for determining viability".

9. GOST 32592-2013 "Seeds of vegetable, melons, root fodder and fodder cabbage. Varietal and sowing qualities. General technical conditions".

10. GOST R 55906-2013 "Fresh tomatoes. Specifications".

11. Neminushchaya L.A., etc. Modern technologies of storage and processing of fruits and vegetables. Scientific analytical review // Moscow: FGNU "Rosinformagrotekh", 2009. $172 p$. 